\title{
THE FIRST RECORDS OF THE OLIVE-SHADED BIRD-DROPPING MOTH, ACONTIA CANDEFACTA (HUBNER, 1831) IN CROATIA
}

\section{Toni Koren}

Association Hyla, Lipovac I 7, HR-10000 Zagreb, Croatia (e-mail: toni.koren@hhdhyla.hr)

Koren, T.: The first records of the olive-shaded bird-dropping moth, Acontia candefacta (Hubner, 1831) in Croatia. Nat. Croat., Vol. 28, No. 2., 469-472, Zagreb, 2019.

During faunistic surveys of the moths of northern Croatia, six specimens of the olive-shaded birddropping moth, Acontia candefacta, were recorded. Five specimens were attracted to light traps at the sandy area of Kloštarski pijesci near Đurđevac, while a single specimen was recorded on the southern slopes of Medvednica Nature Park near Zagreb. This species was deliberately introduced from Canada to Russia in 1969 in order to control the spread of the invasive plant Ambrosia artemisiifolia L., and has so far spread across eastern and parts of central Europe, including Serbia and Hungary. With this survey $A$. candefacta has for the first time been recorded in Croatia, which confirmed the further spread of this species toward western Europe.

Key words: Lepidoptera, Noctuidae, distribution, Ambrosia artemisiifolia

Koren, T.: Prvi nalaz ambrozijine sovice Acontia candefacta u Hrvatskoj. Nat. Croat., Vol. 28, No. 2., 469-472, Zagreb, 2019.

Tijekom faunističkih istraživanja noćnih leptira sjeverne Hrvatske zabilježeno je šest primjeraka ambrozijine sovice, Acontia candefacta. Pet primjeraka privučeno je svjetlosnim zamkama na pješčanom području Kloštarskih pijesaka kod Đurđevca, dok je jedan primjerak zabilježen na južnim padinama Parka prirode Medvednica kod Zagreba. Ova vrsta namjerno je uvedena iz Kanade u Rusiju 1969. godine radi kontrole širenja invazivne biljke Ambrosia artemisiifolia, a dosad se proširila na dijelove istočne i središnje Europe, uključujući Srbiju i Mađarsku. Ovim je istraživanjem A. candefacta po prvi puta zabilježena na području Hrvatske, čime je potvrđeno daljnje širenje vrste prema zapadu Europe.

Ključne riječi: Lepidoptera, Noctuidae, rasprostranjenost, Ambrosia artemisiifolia

The olive-shaded bird-dropping moth, Acontia candefacta (Hubner, 1831) is an owlet moth (Noctuidae) species native to North America (Stojanović et al., 2017). After the uncontrolled spreading of the invasive plant Ambrosia artemisiifolia L., across Europe, this moth species was deliberately introduced from Canada into the territory of Russia in 1969 in order to control the spread of the plant (Poltavsky \& Artokhin, 2006). Afterwards, the spread of $A$. candefacta was noted across Russia (Poltavsky \& Artokhin, 2006), Ukraine (Kujuchкo et al., 2004), Bulgaria (Beshkov, 2010), Hungary (Kelemen et al., 2014) and recently Serbia (StojAnović et al., 2011; 2017)

During the last few years, field trips were carried out across Croatia in order to survey the moth fauna of the country, and this included many previously unvisited areas and regions. Moths were surveyed using pyramidal UV light traps, with two to five traps used per locality. They were usually in operation for 5 hours after dusk.

During faunistic surveys, $A$. candefacta was recorded in two localities in Croatia. The specimens were set, identified, and stored in the private collection of the author. For each record, the exact locality, coordinates, altitude and dates are provided. 


\section{Material examined:}

1. Croatia, Zagreb, Nature Park Medvednica, Vejalnica meadows, 27.8.2019, N45,916944, E16,074444, 454 m a.s.l., 1 ex., obs. \& coll. Toni Koren.

2. Croatia, Kloštar Podravski, Kloštarski pijesci, 21.8.2019, N46,005362, E17,171929, 154 m a.s.l., 5 ex., obs. \& coll. Toni Koren. While the two records are about 85 kilometers apart (Fig. 2), both of them are well in the known distribution

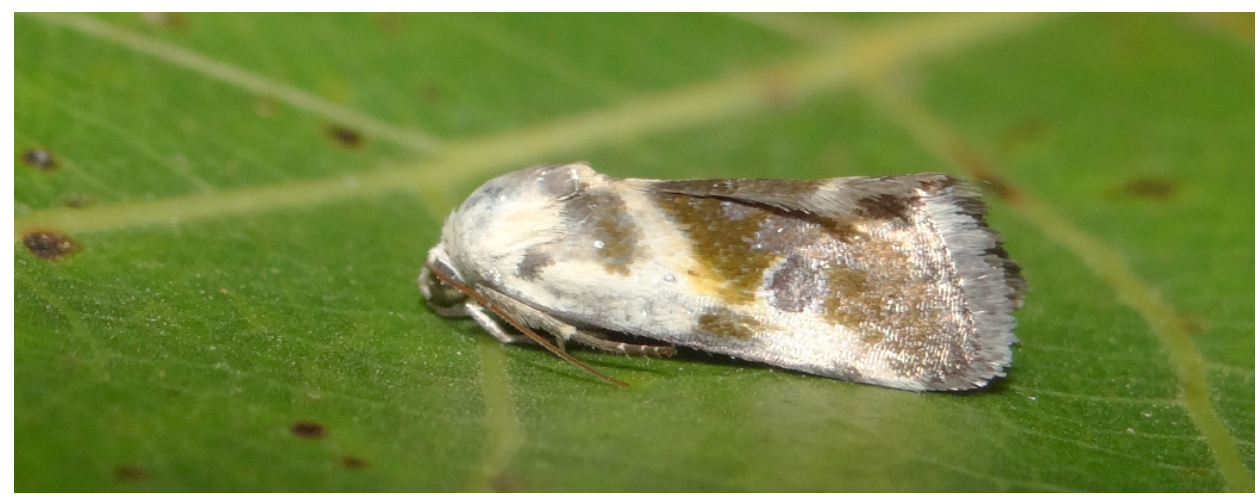

Fig. 1. Acontia candefacta from Kloštarski pijesci near Kloštar Podravski (photo by T. Koren).

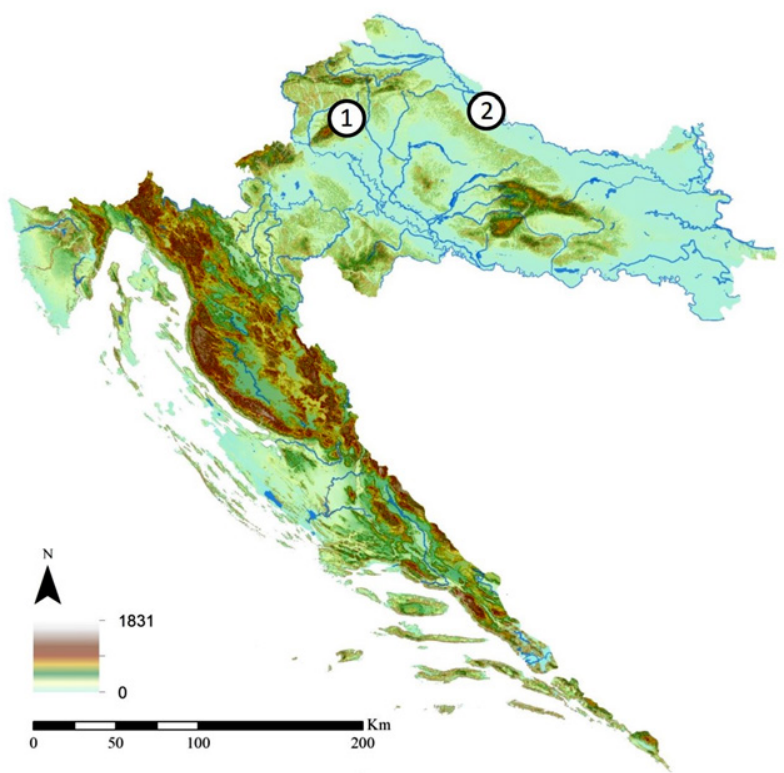

Fig. 2. Records of Acontia candefacta in Croatia; 1. Medvednica Nature Park, Vejalnica meadows, 2. Kloštar Podravski, Kloštarski pijesci.

area of A. artemisiifolia in Croatia (BARIć et al., 2010). At the first observation site, near Kloštarski pijesci, the habitat is in accordance with the observations from Bulgaria, where the species is present on the riparian zone of the Danube River, on sandy habitats (BeshKov, 2010). The Kloštarski pijesci locality was previously 
used for the extraction of sand but has recently been abandoned. As a result, it is overgrown with plant species, including very dense areas almost completly covered in A. artemisiifolia. At the locality, the author searched for the caterpillars and traces of feeding, but was able to record none.

At the second locality, on the south-eastern slopes of Mt. Medvednica, A. artemisiifolia is present only sporadically, and does not cover large areas. As only a single specimen was recorded there, it is possible that the population of this species is located somewhere else in the rural part of Zagreb. At this locality, although regular light trapping has been preformed since 2014, this is the first time that $A$. candefacta was observed.

The finding of $A$. candefacta in Croatia is a confirmation of the spread of this species across Europe, the closest recorded locality being in Vojvodina, approximately $130 \mathrm{~km}$ away (see STojAnović et al., 2017). However, even there in areas of high $A$. artemisiifolia density, no caterpillars were recorded. It would accordingly be necessary to perform intensive mapping of $A$. candefacta in Croatia, using light traps for adults and the host plant surveys for the caterpillars.

It seems that $A$. candefacta cannot control $A$. artemisiifolia in Europe, as no natural outbreaks in abundance of the species have been recorded so far in the new areas it has invaded (Stojanović et al., 2017). Currently, A. artemisiifolia, continues to spread across Europe, probably aided by climate change (MAzzI \& Dorn, 2012). Accordingly, the range of $A$. candefacta can be expected to increase in the future and new records from Croatia as well as from neighboring countries like Slovenia and Bosnia and Herzegovina are expected in the near future.

\section{ACKNOWLEDGMENTS}

The author is grateful to Darija Kranželić for the help and company during the field trip in the Podravina area.

Received October 16, 2019

\section{REFERENCES}

Barić, K., Šćepanović, M., Goršić, M. \& Ostojıć, Z., 2010: Distribution of Invasive Weed Ambrosia artemisiifolia L. in Croatia. Agriculturae Conspectus Scientificus 75(2), 75-81.

Beshkov, S., 2010: Contribution to the Bulgarian Macrolepidoptera fauna (Lepidoptera: Geometridae, Noctuidae). The Entomologist's Record and Journal of Variation 122(4), 175-181.

Kelemen, I., Lévai, S., Majláth, G. \& Majláth, I., 2014: New results of the Macrolepidoptera survey in Kisújszállás and its surrounding areas (Hungary) III. (Lepidoptera: Macrolepidoptera). e-Acta Naturalia Pannonica 7, 33-76.

Kljuchko, Z. F., Budashrin, J. I. \& Gerasimov, R. P., 2004: New and little-known species of noctuids (Lepidoptera) of Ukraine's fauna. Bulletin of Zoology 38(1), 94.

Mazzi, D. \& Dorn S., 2012: Movement of insect pests in agricultural landscapes. Annals of Applied Biology 160(2), 97-113.

Poltavsky, A. N. \& Artokhin, K. S., 2006: Tarachidia candefacta (Lepidoptera: Noctuidae) in the south of European Russia. Phegea 34(2), 41-44.

Stojanović, D. V., Ćurčıć, S. B., Orlović, S., Kereši, T. \& Galić, Z., 2011: Prvi nalaz sovice Ponometia candefacta (Hübner, 1831) (Lepidoptera, Noctuidae) u Srbiji. Biljni lekar 39(1), 31-36.

Stojanović, D. V., Vajgand, D., Radović, D., Ćurčić, N. \& Ćurčić, S., 2017: Expansion of the range of the introduced moth Acontia candefacta in southeastern Europe. Bulletin of Insectology 70, 111-120. 
